\title{
Teachers' beliefs in multilingual education in the Basque country and in Friesland
}

\author{
Elizabet Arocena Egaña, Jasone Cenoz and Durk Gorter \\ University of the Basque Country
}

In this article we analyze teachers' beliefs about learning different languages in multilingual education, which include forms of immersion in the minority and the majority languages. In this study interviews were held with 51 primary school teachers from the Basque Country (Spain), and Friesland (The Netherlands). In both regions three languages are taught: majority, minority and English. Based on the teachers' views we obtain interesting insights into the native speaker ideal, pupils as multilingual speakers, and the proficiency levels for each language. The teachers also expressed their ideas on teaching through the minority language and through English, as well as their beliefs on cross-linguistic use of languages and how that is related to the multilingual repertoire. The social context is believed to have an important influence through the parents, the media, and the status of the languages in society. The article concludes that beliefs are still largely monolingual and seem to only gradually change to more multilingual views.

Basque and Frisian abstracts at end.

Keywords: teacher beliefs, multilingual education, minority language, CLIL, immersion, Basque, Frisian, English

This article focuses on language teachers' beliefs in the context of multilingual education, which includes specifically contexts in which minority and majority languages are used as the medium for subject matter instruction. Teachers' beliefs are considered important because of their link to the decisions teachers make in the classroom (Lucero, Valcke \& Schellens, 2013; Pajares, 1992; Young \& Walsh, 2010). Beliefs can influence pedagogical practices and teachers may accept new approaches and teaching strategies to a more or less extent according to their beliefs. The study of beliefs is important both for pre-service and in-service teachers (Fischl \& Sagy, 2005). 
Some beliefs are widespread within the context of multilingual education, and they are shared by many teachers and education professionals. Cummins (2014) identified some of these far-reaching beliefs which he calls "monolingual instructional assumptions" in French immersion programs in Canada:

- Instruction should be carried out exclusively in the target language without recourse to students' L1;

- No translation between L1 and L2 is appropriate in French immersion programs;

- Within immersion and bilingual programs, the two languages should be kept completely separate. (pp.9-10)

He criticizes these assumptions and explains how they are being challenged nowadays. These assumptions are also widespread in multilingual education in Europe where they are being challenged by proposals that argue for pedagogies that soften the hard boundaries between languages (see, for example, Cenoz \& Gorter, 2011, 2015; Creese \& Blackledge, 2010). Nevertheless, monolingual beliefs have a strong tradition and are still widespread in education.

In this article, we focus on the study of teachers' beliefs in a time when monolingual ideologies are being contested. Teachers' beliefs are examined in the context of two European regions, Friesland (a northern province of The Netherlands) and the Basque Autonomous Community (consisting of the three provinces Alaba, Bizkaia and Gipuzkoa, commonly referred to as the Basque Country, but part of a larger area in northern Spain that also comprises the Foral Community of Navarre and an area in the southwest of France called Iparralde). See Figure 1.

Schools in these regions have a minority language (Basque and Frisian), a national language (Spanish and Dutch), and English as a language of wider communication. There are many similarities between the two contexts but also important differences, particularly regarding the role of the minority language in education, as will be explained in this article.

The aim of this article is to analyze and compare the beliefs that in-service teachers in these two regions have regarding multilingual education. The study of teachers' beliefs has been carried out in the context of a collaborative research project between the University of the Basque Country (DREAM Donostia Research group on Education and Multilingualism $)^{1}$ and the Mercator European Research Centre on Multilingualism and Language Learning ${ }^{2}$ in Friesland. 


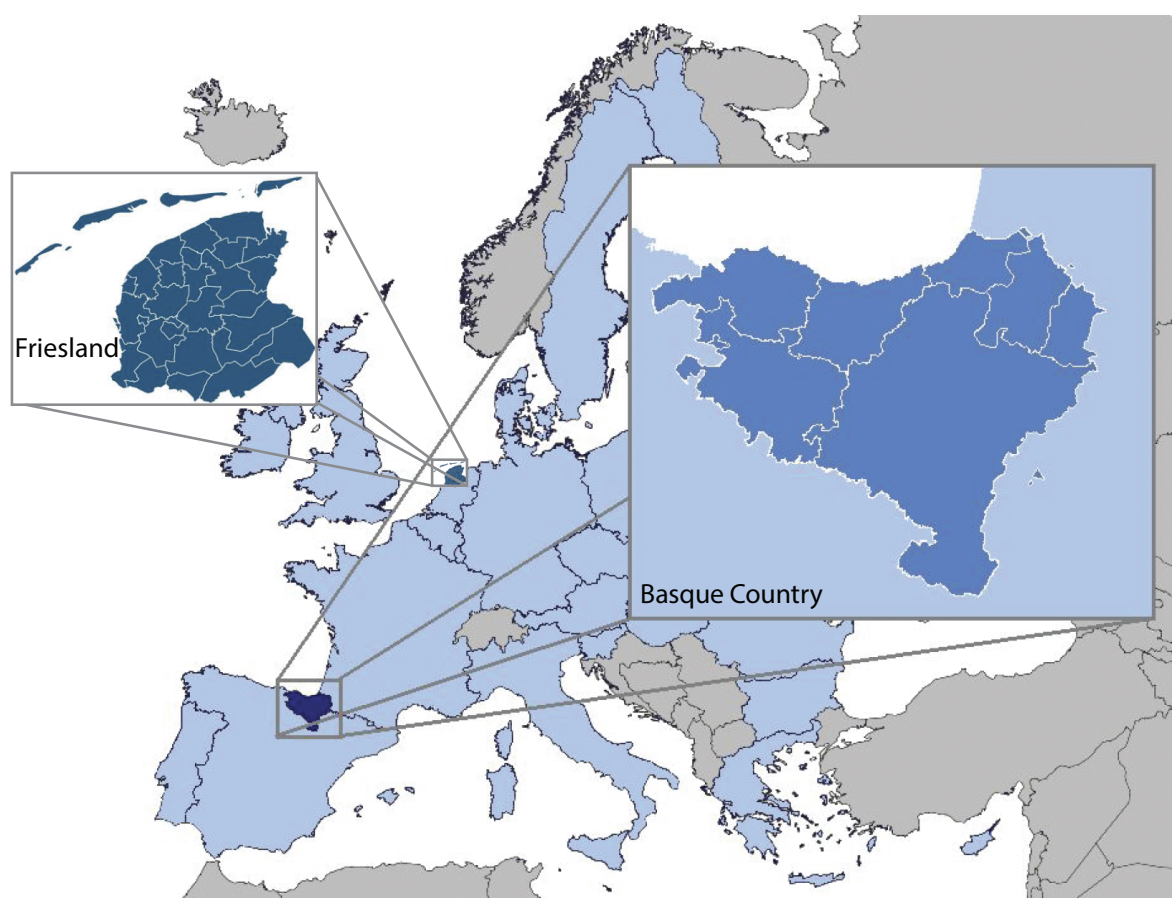

Figure 1. Map of Basque Country and Friesland on the European continent (adapted from maps found at http://en.wikipedia.org/wiki/Basque_Country_(greater_region)\#/ media/File:Euskal_Herria_Europa.png and http://www.overheidinfriesland.nl/template/ map/friesland-1.jpg.

\section{Teachers' beliefs}

Beliefs have been defined as "propositions individuals consider to be true and which are often tacit, have a strong evaluative and affective component, provide a basis for action, and are resistant to change" (Borg, 2011, pp.370-371). In the case of language teachers, the propositions considered to be true are opinions and ideas about learning and teaching languages. However, it is important to acknowledge that the study of beliefs is based on reported information and this has some methodological limitations.

The study of beliefs in language learning has a long tradition when it comes to examining learners' beliefs. There are references to learners' beliefs already in early studies about the "good language learner" (see Jeoffrion, Marcouyeux, StarkeyPerret, Narcy-Combes \& Birkan, 2014). The study of teachers' beliefs has had an important development as linked both to pre-service and in-service teachers. Borg's (2003) conceptualization of Teacher Cognition has been a valuable theoretical contribution to the study of teachers' beliefs. According to Borg (2006, p. 82), 
teacher cognition refers to "beliefs, knowledge, theories, attitudes, images, assumptions, metaphors, conceptions and perspectives about teaching, teachers, learning, students, subject matter, curricula, materials, instructional activities and self." Teacher cognition receives the influence of previous learning experiences (schooling), contextual factors, professional coursework (experience in pre-service and in-service programs), and classroom practice (teaching) (Borg, 2006). According to Borg, the influence of schooling and contextual factors is unidirectional but the other two relationships are bidirectional. Professional coursework and classroom practice not only influence teacher cognition but are also influenced by it. According to Borg (2006), cognition, context, and experience interact with each other in a dynamic way in language teaching.

Nishino (2012) proposed the Model of Teacher Beliefs and Practices for Communicative Language Teaching. In this model, classroom practices are influenced by teachers' beliefs, contextual factors, and perceived teacher efficacy. Nishino highlights the important relationship between teachers' beliefs, teaching practices, and teaching contexts.

The importance of context is also highlighted by other scholars (see, for example, Barahona, 2014; Jeoffrion et al., 2014; Yang \& Gao, 2013). In fact, contextual conditions such as public examinations, curricular decisions by the institutions, or parents' and students' expectations can contribute to shaping teachers' beliefs. In the case of teachers' beliefs on multilingualism, the relative status of the languages in society and the institutional decisions about the curriculum, including the textbooks and materials used, can influence teachers' beliefs. At the same time, parents' expectations and motivations about the different languages can potentially have an important role in teachers' beliefs on multilingualism. Teachers can also have beliefs related to previous learning and teaching experiences and their own pre-service and in-service training.

An important line of research in the study of teachers' beliefs is their relationship with teacher practices. Basturkmen (2012) reviewed a number of studies on teachers' stated beliefs and concluded that the correspondence between beliefs and practices is limited. In many cases, teachers considered that external factors made the correspondence more difficult. Basturkmen (2012) highlights that the relationship between beliefs and practices is interactive. Beliefs can influence practices but practices can have an influence on beliefs as well.

\section{Multilingualism and teachers' beliefs}

Research and teaching languages in school contexts have been influenced by monolingual views (see for example Cummins, 2014). These views are characterized by 
using monolingual native speakers' competence as a reference and isolating languages from each other in the context of the classroom (Young \& Walsh, 2010).

According to monolingual views, language learners have to make progress in the direction of achieving an impossible goal. They have to become ideal native speakers of the target language, who are perfectly competent in all skills in different communicative contexts. This unreachable goal can create a sense of frustration in many learners. This view implies that ideally a multilingual person is a perfect native speaker of several languages. It also implies that multilinguals should be balanced and have the same level of competence in different languages. Cenoz and Gorter $(2011,2014)$, who proposed the model "Focus on Multilingualism," consider that this ideal "monolingual speaker" has to be replaced by a more realistic "multilingual speaker". Multilingual speakers are not unreal perfect native speakers of several languages, but real people who navigate between languages according to the communicative situations. They are not deficient or weak communicators because they are not native speakers of their second, third, or fourth language. They are stronger communicators than monolingual native speakers because they can use their linguistic resources in more communicative situations with more monolingual and multilingual speakers.

Research on teachers' beliefs about monolingual versus multilingual views regarding multilingual speakers is limited. Griva and Chostelidou (2012) did not compare these two views, as we will do in this article, but asked 120 foreign language teachers in Greece about their beliefs regarding multilingualism. The results indicated that multilingualism is believed to be very positive. Another interesting result is related to the teaching of English from an early age in the Basque Country and Friesland. Most Greek teachers who participated in Griva and Chostelidou's study considered that foreign languages (English in most cases) should be introduced in kindergarten because children can learn them more easily. However, one third of the teachers thought that children have to develop a firm foundation in their mother tongue before a foreign language is introduced.

Another deeply-rooted idea that reflects monolingual views is the need to keep languages separate from each other in order to learn them better. As Cummins (2007) points out, this idea emerged from the direct and audiolingual methods for second language teaching, but it is still accepted in contemporary methods as well. The belief that languages should be kept separate is also reported in a study on teachers' beliefs conducted by De Angelis (2011). Participants in this study were 176 school teachers from Italy, Austria, and Great Britain who had immigrant students in their classes. Teachers answered a questionnaire on teachers' beliefs about multilingualism, home language maintenance, and classroom practices in relation to home languages. The results indicated that teachers believe that multilingualism 
has advantages. However, they conceive languages as separate entities, and some teachers believe that languages have to be learned one at a time.

The monolingual view that establishes hard boundaries between languages has been challenged in many different ways. Cenoz and Gorter $(2011,2014)$ refer to the use of the whole linguistic repertoire in "Focus on Multilingualism". The study of multilingual discourse practices in and outside the classroom shows that languages are not separated. García (2009) uses the term "translanguaging" to refer to multiple discursive practices (see also Creese \& Blackledge, 2010; García \& Wei, 2014; Cenoz \& Gorter, 2015). Research on translanguaging often focuses on the analysis of multilingual practices which are hybrid and without clear boundaries. Lewis, Jones, and Baker (2012) use translanguaging as a pedagogical strategy in Welsh-medium instruction that systematically uses one language for input and another language for output in the same lesson. Other scholars look at teachers' and students' use of their L1 or other languages as a resource when acquiring additional languages or in content and language integrated learning (CLIL) or content-based instruction contexts (including immersion) when learning tasks are complex (Luk \& Lin, 2015; Swain \& Lapkin, 2013). A step further is the active use of the first language (L1) in pedagogical interventions to develop metalinguistic awareness and enhance language acquisition and (bi)literacy skills (see, for example, Arteagoitia \& Howard, 2015; Ballinger, 2013; Lyster, Quiroga \& Ballinger, 2013).

In this article we look at Basque and Frisian teachers' beliefs about students' whole linguistic repertoire and the use of cross-linguistic resources. The linguistic repertoire that Basque and Frisian students have is developed in a social context. In fact, multilingual speakers engage in language practices and use their linguistic resources to shape this context. The use of different languages in school contexts and translanguaging can be affected by the status of the languages. This is reported by Chimbutane (2013), who conducted a study on teachers' beliefs about code-switching in Mozambique. He observed that African languages are used in the classroom even if teachers believe that it is better not to mix languages (see also Heugh, 2015). Chimbutane (2013) explains that the lack of tradition of using African languages in education plays a role because teachers and students are more familiar with academic language in Portuguese than in their first languages. In this article we also look at monolingual and multilingual beliefs as related to the social context and the status of the languages in the curriculum. This study addresses some gaps in the literature on teachers' beliefs because it explores beliefs as related to monolingual and multilingual ideologies. Furthermore, the study was conducted in two contexts where three languages can be used to teach content. 


\section{Background and research questions}

\subsection{Educational contexts of the study}

The educational systems in the Basque Country and in Friesland are similar in content and aims. However, there are some differences between both systems, one being the legal duration of compulsory education. In the Basque Country education is compulsory for students between the ages of 6 and 16, while in Friesland it is compulsory for students aged between 4 and 18. In practice this difference is even smaller because almost all children go to pre-primary classes at an earlier age. Primary education in both contexts ends around the age of 12. In this study we focus on teachers who teach in the highest two grades of primary education.

In both the Basque Country and Friesland there are public and private schools. The latter are distinguished differently; in the Basque Country, private schools can be either concertados (grant-aided private schools) or ikastolak (schools that teach through Basque and promote the use of Basque in all spheres of life). In Friesland, private schools are usually based on religious values (mainly protestant, some catholic, and some other). In both cases the government provides full funding for both public and private schools, although the parents may be asked for payment of a relatively small parental fee to finance extra activities, e.g. culture or sports.

In both regions, children can receive education in three languages: the minority language (Basque or Frisian), the dominant language (Spanish or Dutch), and the foreign or third language (English in both regions). In both regions all three languages can be used to teach content, but language education policy is different in each region. In the Basque Country the language policy of the government is aimed at revitalizing Basque and one of the sectors of society where Basque is supported most strongly is education. In Friesland the language policy is much weaker and even if Frisian is an obligatory subject in all schools, the position of Frisian in the educational system is rather modest.

In the Basque Country, the majority language in society is Spanish. It lives alongside the minority language, Basque. Both languages have official status in the Basque Country and both are compulsory in education. Since 1982, all parents have had the right to choose the language of instruction and enroll their children in one of three bilingual models:

- Model A: Originally intended for Spanish L1 students who choose to be instructed in Spanish. Basque is a school subject.

- Model B: Originally intended for Spanish L1 students who want to be bilingual in Spanish and Basque. Both Spanish and Basque are used as languages of instruction for almost $50 \%$ of the time (with variations from school to school). 
- Model D: Originally intended for Basque L1 students who wish to be instructed in Basque. Spanish is a school subject.

Although originally model $\mathrm{D}$ was intended as language maintenance program for students with Basque as their L1, over the years it has become the most popular model, and more and more students with Spanish as their L1 are enrolled in it. This is due to the demand for Basque in society and the fact that research shows that students in model D become proficient in Basque unlike the students in the other two models (Gorter, Zenotz, Etxague \& Cenoz, 2014). As a consequence, enrollment in model A has declined and enrollment in model B has remained more or less steady (about 20\%). Thus, most children in the Basque Country are instructed through the medium of Basque regardless of their mother tongue, in fact, most students' L1 is Spanish.

The early introduction of English in kindergarten (ages 0-6) was initiated in the 1990s following the idea that more years of exposure to English would result in higher levels of proficiency (Gorter \& Cenoz, 2011). In all three models English is taught alongside Basque and Spanish. The Basque Department of Education specifies in its curriculum guidelines the number of hours of instruction per week for each of the three languages. In primary school, depending on the grade, Basque and Spanish have to be taught between 3.5 and 4 hours and English between 2 and 3 hours as a subject. Each school can decide which subjects it wants to teach through the medium of each language, for Basque and Spanish that leads to the different models which can exist side-by-side in one school. For English most schools provide instruction in one or two subjects, for example, Science or Arts and Crafts.

In Frisian schools the situation is almost the reverse; about half of the children's home language is Frisian and in all schools the predominant language of instruction is Dutch. There are no linguistic models similar to the Basque models in the Frisian schools; Dutch is the main language of instruction but schools have been obligated to teach Frisian as a subject since 1980. In the Netherlands schools can decide themselves how many hours of instruction they teach in each language, and there are no norms from the Ministry of Education. The most common pattern is to teach Frisian for half an hour per week in the two lowest grades and for one hour in Grades 3 to 8. As a medium of instruction Frisian is used on a modest scale by about $20 \%$ of all schools (Gorter \& Cenoz, 2011) in those schools teachers may use Frisian for one day or half a day, thus for about 3 or 6 hours per week. In 1986, English became obligatory in primary schools but it is usually taught only in the upper two grades (7 and 8) for about one hour per week. In 1997, a trilingual schools' project was established in seven primary schools in order to improve the quality of education and especially of Frisian and English (Riemersma \& De Vries, 
2011). Over the years, the number of schools involved in that project has grown to over 40 out of almost 500 primary schools in Friesland. In these trilingual schools Frisian and Dutch are each used for subject matter instruction for about $40 \%$ of the time and English for about 20\%, although in the lower grades there will be less English. Some of the trilingual schools are experimenting with the early introduction of English at the age of 4 or of 6 .

Thus in both the Basque Country and in Friesland, in addition to the minority and the dominant languages, a third language, English, is taught in primary schools always as a subject and in many cases also as a medium of instruction for one or two subjects. Although English is considered a third language in both regions as in many other European countries, in the Basque Country it is also a foreign language not used in everyday communication (Cenoz, 2009).

This study was designed to investigate teachers' beliefs concerning multilingual education in general and their views about their pupils as multilingual speakers in particular.

\subsection{Focus on Multilingualism and research questions}

The specific research questions are related to the three dimensions of the "Focus on Multilingualism" approach (Cenoz \& Gorter, 2011, 2014). "Focus on multilingualism" is an approach to teaching and research in education that relates the way multilingual students (and multilingual speakers in general) use their communicative resources in spontaneous conversation to the way languages are learned and taught at school. The three dimensions of this model are (i) the multilingual speaker, who is different from a monolingual speaker and has to be treated as such, (ii) the linguistic repertoire, where all the languages in the speaker's repertoire are included instead of looking at one language at a time, and (iii) the social context, where the use of languages in interaction and language practices are taken into account; this also considers the use of languages in society at large.

We address the following three questions:

1. What are the beliefs of teachers concerning the multilingual speaker?

2. What are the beliefs of teachers concerning the whole multilingual repertoire?

3. What are the beliefs of teachers concerning the social context? 


\section{Method}

\subsection{Participants}

The first step was the selection of primary schools in the Basque Country and Friesland and then the selection of teachers to be interviewed. We selected ten schools in the Basque Country and nine in Friesland. The criteria were that each of these schools served at least 200 students, were at the primary school level, included both public and private schools, and were located in different language environments. The teachers we selected had to teach in at least one language in the last two years of primary education (serving students aged 11-12) in both contexts. As they are primary school teachers, most of them combine teaching language as a subject, with teaching content subjects as well. In total, 33 teachers from Basque schools and 18 from Frisian schools were interviewed.

Among the 51 teachers, 35 were female and 16 male. Their ages varied from 22 to 61 years. Some of them were beginning young teachers, most were middleaged and a few were close to retirement. Their teaching experience varied from one or two years in several cases up to 40 years in one case; on average they had taught for 19.4 years. These teachers' mother tongue was the minority language for 34 participants (22 Basque and 10 Frisian) and the dominant language for 17 (10 Spanish and 7 Dutch). One teacher in Friesland and another in the Basque Country reported they have both the minority and dominant language as their mother tongue.

\subsection{Instruments and procedure}

The main data collection instrument is a semi-structured interview schedule. The schedule includes two short sections on (1) the teacher's background and (2) general organization of the school, then two longer sections on (3) language beliefs and (4) language practices, and finally a short section on (5) testing/evaluation. Examples of such questions are: "What are the goals of language learning and the levels to achieve? What do you think about the use of English as a medium of instruction? What is your opinion on CLIL and immersion? In your opinion, what are the advantages and disadvantages of multilingualism? What are the most useful teaching techniques for language learning? Do you allow code-switching among the students? Can students answer in a different language than the language of instruction?"

All questions were open-ended and depending on the answer, a topic could be probed further and the teacher could be asked to elaborate on his or her answer. The questions were in particular aimed at the exploration of the language beliefs 
of the teachers in the context of multilingual education. The interviews were conducted in the language of the teacher's choice, which meant that all but one in the Basque Country were in Basque and in Friesland it was about half in Dutch and half in Frisian.

Three researchers carried out the interviews during a period of two months. The interviews were voice-recorded and held individually with each teacher. After all interviews had been completed, the researchers proceeded to transcribe the recordings. The interview protocols were then entered into, coded, and analyzed with the Atlas.ti program for qualitative data analysis (QDA). The researchers discussed coding following the interview protocol and then organized all transcripts systematically, and almost all the texts were translated from Frisian, Dutch, Basque, or Spanish into English. A fourth researcher along with one of the first then collaborated step by step analyzing the different themes and selecting quotes to highlight similarities and differences between the two regions, thereby taking frequency, saliency, and relevancy into account. As a first outcome a descriptive report was written for the grant-giving organization (Arocena \& Gorter, 2013). ${ }^{3}$

\section{Results}

In this section we will discuss the main findings of the interviews. First we will look at the general advantages and disadvantages of multilingualism that the teachers mentioned. Then we discuss the outcomes in terms of the three dimensions of the "Focus on Multilingualism" approach. We present teachers' beliefs about the multilingual speaker and language achievement levels, their beliefs about the whole multilingual repertoire of the pupils, which are divided according to the teaching through the minority language, teaching through English, and their beliefs on cross-linguistic uses of language. The influence of the social context is discussed in terms of their beliefs about the influence of parents, of the media, including television and social networks and, finally, the influence of society in general.

5.1 Beliefs about the general advantages and disadvantages of multilingualism

The primary school teachers from the Basque Country and from Friesland have given us important insights into their beliefs about multilingualism in education. When we asked them about their general views about the advantages and disadvantages of multilingualism, almost all teachers highlighted advantages. They mentioned similar advantages and only a few teachers expressed some doubts or mentioned a disadvantage of multilingualism. The following teacher expressed a generally held opinion well: "I am very happy with multilingualism. The more 
languages you know the better. I do not see any disadvantages" (EUS2). ${ }^{4}$ Some more specific advantages repeatedly mentioned were about the ability to communicate with speakers of other languages and get to know other cultures, as well as a positive relationship of multilingualism to intelligence and socioeconomic advantages in terms of future jobs. The teachers had a shared belief that "to be multilingual gives you many opportunities" (EUS20). For them as teachers in schools where three languages play an important role it is of significance that they have positive attitudes towards the teaching of the three languages and towards multilingualism in general. Only a few teachers identified disadvantages, mainly in terms of a higher study load, a lack of sufficient time to learn the languages equally well or the difficulty "to achieve the highest level in all languages" (EUS28). This was related to how they view their pupils as multilingual speakers and what levels can be achieved.

The positive view of multilingualism was also reported by Griva and Chostelidou (2012). In their study, some teachers associated multilingualism with the ability to communicate in different cultural and linguistic environments and the openness to other languages and cultures. In a study by De Angelis (2011) teachers also believed that knowing several languages was important.

\subsection{Beliefs about the multilingual speaker and language achievement levels}

The first research question concerns how teachers view their pupils as multilingual speakers in terms of the goals of language learning. Is their aim that their pupils become like native speakers in all three languages? Can the same level of language proficiency be achieved for each language?

On the issue of the native speaker as an ideal, the responses seemed superficially to indicate a split of opinion among the teachers; 30 out of 51 teachers gave positive answers that started with "yes" or "that would be good". They confirmed that their conceptualization of attainment levels was derived from the concept of native speaker. In contrast, the second group of 21 teachers gave a negative answer, for example, "nobody gets a native level" (EUS10). They did not seem to think that a native speaker level is an adequate aim for their pupils now, or in the future. However, a closer look at each of their statements makes clear that the initial answer tended to be further qualified and elaborated upon so that in the end most teachers agreed in important ways about the native speaker as an important, but unreachable, goal.

A native speaker level may be seen as desirable and an initial positive answer would often be followed by a clarification along the lines of "aiming for it is always good" (FRY42) or "[Of course] pupils need to master both Basque and Spanish very well" (EUS7). It seems that for many teachers the native speaker is the ideal, but at 
the same time they agreed that in reality this level may not be achieved or at least it is hard to reach. This perspective led a Basque teacher to reflect on her own skills: "I do not have the same level in Spanish as I do in Basque" (EUS22) and the thought about not being a "perfect balanced bilingual" is probably shared by many teachers. Even if the Basque teachers agree that the aim for their pupils is to become bilingual in Basque and Spanish at high levels, this belief does not imply complete equality. Reflecting on the aims for English, many teachers added a further qualification. Some said "We should aim at that [native] level in each language, not just in Spanish, also in English" (EUS24). These teachers have in common a certain frustration that the ideal of the native speaker is too hard to attain. Their colleagues who negatively answered the question about native speaker norms usually stated that they aim for "communication" skills: "No, languages are for communicating, so the pupils should get a communicative level" (EUS6).

Most Frisian teachers share the belief that the goal of language learning should be a native speaker level for Dutch, for the other two languages there seemed to be less agreement. Some of them were less explicit about the level they want to achieve for Frisian, and they seemed to care less or do not know well what the aims are, as one says: "I don't know, I just follow the method and do what I have to do" (FRY38). One teacher shared a negative perception about the teaching of Frisian and thus about the aims for achievement in Frisian: "Children who are Frisian don't learn anything from it and those who are not Frisian do not learn either" (FRY40). All Frisian teachers, without exception, take it for granted that the level to obtain for Dutch has to be higher than that for Frisian. Their belief was summed up as: "Dutch is the main language, Frisian is just extra" (FRY39). For English, the Frisian teachers do not seem to aim very high for these primary school pupils either.

Taken together the answers show a major difference between the Basque and the Frisian teachers. The Basque teachers want their pupils to get a high level in both the minority and the dominant language and an intermediate level in English, whereas the Frisian teachers give priority to the dominant language, Dutch, and aim much less high for the minority language, Frisian. They also do not seem to have high aims for English in primary school. This divergence reflects the importance the two groups of teachers give to the three languages and in the beliefs about their pupils as multilingual speakers.

\subsection{Beliefs about the whole multilingual repertoire of the pupils}

This section about the whole multilingual repertoire of the pupils will be divided into two parts: (1) teaching through the medium of the minority language and through English and (2) cross-linguistic language use such as code-switching, transfer, and translations. These aspects will be considered in answering the 
second research question about the beliefs of the teachers concerning the whole multilingual repertoire.

\subsubsection{Teaching through the minority language}

The role of the minority language as a medium of instruction is rather different in the Basque Country and Friesland, as was made clear in the section on Background. The teachers' beliefs on teaching through Basque or through Frisian diverge accordingly. The main difference is that Basque teachers completely accept and have a positive opinion about the use of the minority language, while the Frisian teachers show reactions which, with some variation, point more to negative than positive beliefs on the use of the minority language for teaching. Not a single Basque teacher looked negatively upon the use of the minority language; most of them believe it is "natural" or "good" and several teachers spoke out in favor of the use of the minority language, whereas the range of opinions provided by the teachers in Friesland is more towards the opposite side of the spectrum. The opinions vary from teaching the minority language under certain conditions, to more negative views that revealed several obstacles. The Frisian teachers who only teach Frisian as a subject are generally not in favor of teaching through the medium of Frisian. Even those who teach through Frisian themselves have mixed feelings and they are far less positive than their Basque colleagues. Some of them have a more or less positive opinions, for example, on condition that its use is limited: "on the Frisian parts of the day" (FRY35). One teacher shared this belief: "When you are at a trilingual school and you have got an English day and a Frisian day, then it is okay to teach in Frisian" (FRY34). Some other teachers may feel more or less negative about teaching a content subject through the medium of Frisian, which can be due to, as some have indicated, a lack of preparation, insufficient language skills, or lack of willingness to do so. Also a lack of textbooks or methods in Frisian was mentioned. Some think content-based instruction through the medium of Frisian may pose an obstacle for the pupils: "They don't mind History in Frisian but they find it difficult" (FRY43). One content teacher reported a solution for this problem: "I teach History in Frisian. We read the Dutch text and we discuss the text in Frisian" (FRY46). He applies, probably without being aware of the term, the practice of pedagogical translanguaging (Lewis et al., 2012). One subject teacher spoke out clearly against the use of Frisian as a medium of instruction: "No, I am not in favor" (FRY44). His opinion is perhaps not politically correct among teachers, but he vocalized an opinion that seems common among parents and in society, at least they are perceived as not supporting Frisian. In summary, in the case of Friesland, the use of the minority language as a language of instruction is limited and conditioned for several reasons. 


\subsubsection{Teaching through English}

In both regions English is the third language taught in schools, and the teaching of English is an important issue in both educational systems. The teachers' beliefs on the use of English as a medium of instruction are quite different from their views about the minority language as a medium of instruction. The issue is not whether English should be taught or not, because that is taken for granted, but they have different ideas about when to start, how much instructional time should be devoted to English, and which pedagogical approaches to use.

For most teachers CLIL is related to teaching content matter through English, not to Basque or Frisian. However, not all teachers are convinced that CLIL is a good idea, and not all teachers want to give priority to CLIL. For example, a Basque teacher says: "Well, it is okay to have one class in English, but I think they have enough with getting to know their own mother tongue well" (EUS33). In Friesland not all teachers are convinced either, or, as one of them put it: "Someone who has already trouble with maths is supposed to be taught maths in English? Well, I do not think that is a good idea" (FRY36). In general, the teachers have concerns about the lack of sufficient language abilities of all of their pupils: "one or two follow but the rest do not (...) many pupils get lost" (EUS4). Even if they have a positive attitude they may see the lack of proficiency of the pupils as too much of an obstacle: "I would like to teach English in English but right now they would not know what I mean" (FRY37).

Teachers who have experience in teaching through English report that their original doubts have been overcome once the results have been positive: "I had my doubts, but the pupils did well, the surprise was good. So we have implemented it in primary Grades 5 and 6" (EUS15), and similar ideas were shared by a Frisian teacher: "I taught creative arts also in English and that went okay" (FRY46). It seems the beliefs about English are influenced by their experience or lack thereof.

\subsubsection{Beliefs on cross-linguistic uses of language}

Teachers in the Basque Country believe that languages should be separated to a larger extent than Frisian teachers. Nevertheless, they are aware that cross-linguistic use of languages, such as code-switching, occurs regularly, because in a setting where pupils and teachers both speak more than one language, code-switching is bound to happen.

During the interviews the teachers indeed confirmed that code-switching frequently happens in a natural way in their classroom. Yet, teachers believe it is better not to allow their pupils to code-switch because they want only the language of instruction to be used. In the Basque Country almost all teachers try to correct their pupils when they switch between languages. Those teachers encourage the use of the target language: "If a pupil responds in Basque in an English or Science 
class, I repeat in English and encourage them to repeat in English, I would not reprimand him" (EUS7). Several teachers emphasize that they do not want to correct the pupils all the time because then: "They get tired" (EUS10), "They would become quiet" (EUS3), or "They get embarrassed" (EUS6). The Frisian teachers seem even more aware that a negative approach to code-switching can be counterproductive: "I correct it but in a sympathetic way. They have to be motivated to speak English but when you are too hard on them they do not dare anymore" (FRY48). The Frisian teachers generally are more relaxed about code-switching, most of them "do not mind" when their pupils do not use the language of instruction at all times. These teachers much less emphasize using English during the English lessons and some even say that code-switching for them is a teaching strategy. To teach English through the medium of Dutch is rather common in Frisian schools and is seen as uncommon in Basque schools, because the beliefs in language separation are much stronger among Basque teachers.

Because at the primary level all or almost all subjects are taught by the same classroom teacher, the teachers have become aware that there are skills and concepts that are the same in different languages. One teacher observed: "because I teach both Basque and Spanish I make links to each subject (...) With the English teacher we do comment on pupils' progress but not about coordination of the subjects as we do with Basque and Spanish" (EUS6). In the Basque Country some schools are convinced of the importance of an integrated treatment of all languages and some of their staff members have attended a specific training course: "We want to work on 'integrated language treatment' and from now on, we do intend to have meetings with teachers of all languages together" (EUS7). This attitude reflects an openness to change from a separated to a coordinated approach.

These teachers in the Basque Country referred to an integrated and coordinated approach to languages in the curriculum that allows for the transfer of what is learned in one language to the other languages. A similar program for integrated languages teaching was not mentioned in Friesland, although Frisian teachers also will probably share the belief that you are able "to pass along the skills you have in one language into another, so you will use the three languages well" (EUS12). Because the Frisian teachers are less strict about language separation, they use translation more often as a strategy in their classes: "Of course, you translate English words. They have to know what they are writing down" (FRY47). For Basque teachers translation is a last recourse "translation would be the last thing to do" (EUS31).

Even if the Frisian teachers in practice separate languages less strictly than the Basque teachers, several Frisian teachers point to language separation as a factor that can contribute to the success of multilingual education, as the following quotes illustrate: "it can be only successful if you consequently separate the languages" (FRY39), "Teach Frisian, Dutch and English as separate subjects" (FRY44), and 
"You have to make good arrangements and separate the languages well" (FRY46). In both cases we find a contrast between beliefs and practices; on the one hand, Basque teachers practice separation but believe they have to allow for mixing, and Frisian teachers practice mixing but believe in separation.

\subsection{Teachers' beliefs about the influence of the social context}

There are several factors outside the school which can have an influence on the pupils' learning of languages. Our third research question concerns the beliefs of the teachers about the social context in relation to multilingualism as an aim for the pupils. The factor social context was not perceived in the same way by all teachers and again we saw some interesting similarities and differences between the Basque and Frisian teachers. We have grouped the beliefs into three broad factors: the influence of the parents, the media, and society in general.

\subsubsection{Influence of parents}

Parents do have an important influence on their children and on the learning of languages, on this all Frisian and Basque teachers do agree. One Basque teacher is even convinced that "the parents have more influence than we do" (EUS28).

The teachers sense the influence of parents through the language attitudes the children bring to the school which they have acquired from their parents. The parents' expectations have consequences for language learning aims, because the attitudes of the parents are not the same toward each of the school languages. The desire for English is strong among parents and their attitude toward English is important for the Basque teachers, as expressed by two teachers whose thoughts are shared by several: "Parents really want English" (EUS29) and even "English for them is more important than maths" (EUS5). Basque teachers mentioned that many parents send their children to English language academies or private lessons which create differences between pupils that, in turn, have had an influence on their own teaching of English. The phenomenon of private English lessons does not exist in Friesland, but similar to Basque parents, Frisian parents also value English: "Parents are positive about the trilingual school, especially about English" (FRY35).

Teachers also shared the belief that parents sometimes have different valuations of the learning of English and of Basque: "English is better accepted because it is a world language while Basque is just local" (EUS14). This opinion is probably exceptional given the general importance attributed to Basque and teachers' strong preference for Basque medium education. Frisian teachers believe that the value parents give to Frisian can be quite low: "Parents have an important role in the appreciation of Frisian. If children think it is unimportant, that is something they 
are told at home" (FRY40). The parents can even be a reason for not using Frisian as medium of instruction, because "the parents are not interested" (FRY41).

Concluding this section, it can be said that in both regions the teachers believe the attitudes of the children are usually a reflection of the parents' attitudes and expectations. This implies that they give a high value to learning English, and that Basque as a minority language is valued, but not always in practice, whereas the importance given to the teaching of Frisian is low.

\subsubsection{Influence of media: television and social networks}

Society in general, and television, social media, and computer games in particular, are among the sources that influence the language learning processes of the pupils. In the Basque Country there are two television channels through Basque and numerous channels in Spanish. There are several programs for children, some in Basque and many in Spanish. With few exceptions, programs that were originally in English, for example American series or movies, are dubbed into Basque (and on other channels into Spanish); only in some digital broadcasts the original sound can be made available. Most of the teachers are convinced that television has a strong influence on children at this age. The Basque teachers pointed to a shift in the interest of children at around 12-13 years: "The influence from TV is huge. When they are little they watch the Basque TV but when they reach the age of 12-13, they choose other more attractive channels which are in Spanish" (EUS13). It implies that the teachers from that age onward obtain less support for Basque from television and have to struggle against the influence of Spanish. Some Basque teachers believe that having television programs in English would help their pupils to advance: "This is not an English speaking area...we need TV in English, more input" (EUS4).

In Friesland there is only one channel through Frisian with few programs aimed at primary school children. The other channels in the Netherlands broadcast in Dutch and also have many programs with the original sound in English and subtitles in Dutch. Where Basque teachers believe television programs have a huge influence on the use of Spanish, the Frisian teachers are equally convinced of the strong influence of television (and popular music) on knowledge of English: "The pupils already know a lot of English words because they watch English television programs and because they listen to English songs" (FRY34). Television, in other words, is believed to facilitate learning English.

Today, social media such as Facebook also have an influence. They influence the pupils' language use and they may have an effect on their knowledge and use of Spanish, but also of Basque. One Basque teacher observed: "Those [pupils] in 5th and 6 th grades do use them [social media]. There they mainly use Spanish but are using Basque more and more" (EUS33). So in contrast to television, the social media 
may provide some support for Basque. The Frisian teachers again focused on how social media and computer games influence learning English. One teacher shared firsthand experience: "I have some boys in the classroom who play a lot of computer games at home... they are far better at English than the other pupils" (FRY39). There was no mention of the use of Frisian in social media, which in practice is very limited.

In summary, the views of teachers about the influence of television, social media, and computer games are related to general differences in society regarding the use of the three languages in the media. The minority language Basque is believed to receive support from television (up to a certain age) and from social media (once the pupils start using them). Frisian, in contrast, does not receive any support from the media according to the teachers. Frisian teachers believe, however, that children also learn English from outside sources such as the media. Learning English from televisions, social media, or games hardly plays a role in Basque teachers' beliefs, which does not come as a surprise given the relatively modest presence of English in Basque media and society.

\subsubsection{Influence of society in general}

The teachers perceive social context as an important factor which facilitates language learning of Basque when it has a strong presence in the direct environment of the school. In contrast, if Basque is used much less in the social context and it remains confined to the classroom, the context may become an obstacle for language learning. This sounds all rather as an obvious truth, but it is interesting to note how the teachers share certain beliefs. For example, they drew attention to differences for Basque in different geographic parts of the Basque Country. In one case the context was perceived to have a positive influence: "Ours is a good environment to learn Basque, better than in other Basque areas" (EUS4) but in less Basque-speaking areas teachers believe that there is not enough Basque: "They only use Basque here at school, everything they do outside is in Spanish" (EUS10).

Some teachers in Friesland referred also to their own geographic area or their specific local situation as to how they think it has an influence on the possibility to teach (more) Frisian: "I understand that it might be nice [to use more Frisian], but things are different here [in our town]" (FRY41). One teacher was convinced it is impossible to teach through Frisian even if he would want it himself: "I wish it were different ..., because Frisian is my mother tongue, but that is how our society wants it" (FRY42).

In general teachers' beliefs reflect the importance of the social context, in the sense that the multilingual competence of the pupils is not only a matter of the school or of their teaching, but is influenced to a large degree by the social surroundings of the school and the status of the different languages in society in general. 


\section{Conclusion}

This study shows that teachers in two regions where a minority language, a national language, and English are part of the curriculum share some beliefs about multilingualism. The study also indicates that there are important differences between the two contexts. Basque and Frisian teachers hold very positive beliefs about multilingualism. Our results confirm those of teachers in Austria, Italy, Great Britain, and Greece as reported by Griva and Chostelidou (2012) and De Angelis (2011).

Teachers' beliefs regarding the three dimensions of "Focus on Multilingualism", the multilingual speaker, the whole linguistic repertoire, and the social context, provide useful insights on monolingual and multilingual ideologies. Both Basque and Frisian teachers believe that the ideal monolingual speaker is the reference for each of the languages but at the same time they are aware of the fact that achieving ideal native speaker competence is an unreachable goal. There is some tension between the real and the ideal but they seem to consider one language at a time and there were no references to the fact that their students are emergent multilinguals who are different from monolinguals. The data also indicate that the goals for Basque are a lot more ambitious than for Frisian due to differences in the social context, including the strength of language education policies.

Teachers' beliefs regarding the whole linguistic repertoire confirm that the "monolingual instruction assumptions" identified by Cummins (2014) are also pervasive and persistent in the Basque Country and Friesland, but there are some interesting differences between the two contexts. Frisian teachers believe that using the L1 as a scaffold in English language classes can have advantages. Basque teachers' beliefs are more complex. On the one hand, there is a strong idea of isolation and using translation as a last possible recourse, and on the other hand, some teachers believe that the teaching of the three languages should be coordinated. Beliefs against mixing languages are strong in the Basque Country where Basque is the main language of instruction but is a minority language. There is a general idea in society and at school that code-switching could have negative implications for the weaker language. The beliefs about using only the target language in English lessons may be influenced by monolingual ideologies spread in preservice and in-service courses in the Basque Country. At the same time, teaching the three languages in an integrated language curriculum could enhance the use of students' linguistic and metalinguistic resources and enhance learning (Cenoz \& Gorter, 2015). These beliefs about integration show a slight trend towards multilingual ideologies.

Both Basque and Frisian teachers believe that teaching English is important but there are differences regarding the use of the minority language as the language of instruction. Basque teachers have a long tradition of teaching through Basque 
and take it for granted. Frisian teachers' beliefs are quite different. Although it would be a good idea to teach more content through the medium of Frisian to increase the status of the language, it seems that the shortage of materials, adequate teacher training, and a lack of tradition of teaching through Frisian has an effect, as was also reported by Chimbatuta (2013) in relation to African languages and Portuguese as an academic language.

This study also confirms the role of the social and educational context in the development of teachers' beliefs (Basturkmen, 2012; Borg, 2006; Nishino, 2012). Teachers believe that parents and social media have an important influence in learning languages. Their beliefs also reflect the differences in the institutional support for the minority language and the differences in the use of English in the two social contexts.

An important implication for teacher training could be to incorporate more clearly a critical attitude toward monolingual assumptions and also an awareness of the importance of treating the students as multilingual speakers in their own right. Nowadays monolingual ideologies in multilingual education are being replaced by multilingual ideologies that soften the boundaries between languages so as to use the resources multilingual speakers have at their disposal. The results of this study indicate that monolingual assumptions are still strongly rooted among teachers. More research evidence on the advantages of multilingual approaches is needed to influence teachers' beliefs and practices towards a truly "Focus on multilingualism".

\section{Notes}

1. More information about the DREAM research group at the University of Basque Country can be found at http://multilingualeducation.eu/en/.

2. The Mercator European Research Centre on Multilingualism and Language Learning is further described at http://www.mercator-research.eu/.

3. We would like to acknowledge the funding by the Spanish Ministry of Economy and Competitiveness EDU2012-32191 and the Basque Department of Education, Research and Universities IT-362-10 (UFI 11/54).

4. Teachers quoted in the text from the Basque Country are referred to as EUS and from Friesland as FRY followed by a unique identification number. 


\section{References}

Arocena, E., \& Gorter, D. (2013). The multilingual classroom in primary education in the Basque Country and in Friesland: Beliefs of teachers and their language practices. Leeuwarden/ Ljouwert: Mercator European Research Centre on Multilingualism and Language Learning. Arteagoitia, I., \& Howard, L. (2015). The role of the native language in the literacy development of Latino students in the U.S. In J. Cenoz \& D. Gorter (Eds.), Multilingual education: between language learning and translanguaging (pp.61-83). Cambridge: Cambridge University Press.

Ballinger, S. (2013). Towards a cross-linguistic pedagogy: Biliteracy and reciprocal learning strategies in French immersion. Journal of Immersion and Content-Based Language, 1(1), 131-148. DOI: 10.1075/jicb.1.1.06bal

Barahona, M. (2014). Pre-service teachers' beliefs in the activity of learning to teach English in the Chilean context. Cultural-Historical Psychology, 10(2), 116-122.

Basturkmen, H. (2012). Review of research into the correspondence between language teachers' stated beliefs and practices. System, 40, 282-295. DOI: 10.1016/j.system.2012.05.001

Borg, S. (2003). Teacher cognition in language teaching: A review of research on what language teachers think, know, believe, and do. Language Teaching, 36, 81-109.

DOI: $10.1017 /$ S0261444803001903

Borg, S. (2006). Teacher cognition and language education: Research and practice. London: Continuum.

Borg, S. (2011). The impact of in-service education on language teachers' beliefs. System, 39, 370-380. DOI: 10.1016/j.system.2011.07.009

Cenoz, J. (2009). Towards multilingual education: Basque educational research from an international perspective. Bristol: Multilingual Matters.

Cenoz, J., \& Gorter, D. (2011). Focus on multilingualism: A study of trilingual writing. The Modern Language Journal, 95, 356-369. DOI: 10.1111/j.1540-4781.2011.01206.x

Cenoz, J., \& Gorter, D. (2014). Focus on multilingualism as an approach in educational contexts. In A. Creese \& A. Blackledge (Eds.), Heteroglossia as practice and pedagogy (pp. 239-254). Berlin: Springer. DOI: 10.1007/978-94-007-7856-6_13

Cenoz, J., \& Gorter, D. (Eds.). (2015). Multilingual education: Between language learning and translanguaging. Cambridge: Cambridge University Press.

Chimbutane, F. (2013). Codeswitching in L1 and L2 learning contexts: Insights from a study of teacher beliefs and practices in Mozambican bilingual education programmes. Language and Education, 27(4), 314-328. DOI: 10.1080/09500782.2013.788022

Creese, A., \& Blackledge, A. (2010). Translanguaging in the bilingual classroom: A pedagogy for learning and teaching. The Modern Language Journal, 94, 103-115.

DOI: $10.1111 /$ j.1540-4781.2009.00986.x

Cummins, J. (2007). Rethinking monolingual instructional strategies in multilingual classrooms. Canadian Journal of Applied Linguistics, 10, 221-240.

Cummins, J. (2014). Rethinking pedagogical assumptions in Canadian French immersion programs. Journal of Immersion and Content-Based Language Education, 2(1), 3-22.

DOI: 10.1075/jicb.2.1.01cum

De Angelis, G. (2011). Teachers' beliefs about the role of prior language knowledge in learning and how these influence teaching practices. International Journal of Multilingualism, 8(3), 216-234. DOI: 10.1080/14790718.2011.560669 
Fischl, D., \& Sagy, S. (2005). Beliefs about teaching, teachers and schools among pre-service teachers: The case of Israeli-Bedouin students. Language, Culture and Curriculum, 18(1), 59-71. DOI: 10.1080/07908310508668733

García, O. (Ed.). (2009). Bilingual education in the 21st century: A global perspective. Chichester, UK: Wiley-Blackwell.

García, O., \& Wei, L. (2014). Translanguaging: Language, bilingualism and education. New York, NY: Palgrave Macmillan.

Gorter, D., \& Cenoz, J. (2011). Multilingual education for European minority languages: Innovative approaches in the Basque Country and Friesland. International Review of Education, 57(5), 651-666. DOI: 10.1007/s11159-011-9248-2

Gorter, D., Zenotz, V., Etxague, X., \& Cenoz, J. (2014). Multilingualism and European minority languages: The case of Basque. In D. Gorter, V. Zenotz \& J. Cenoz (Eds.), Minority languages and multilingual education: Bridging the local and the global (pp.278-301). Berlin: Springer. DOI: $10.1007 / 978-94-007-7317-2$

Griva, E., \& Chostelidou, D. (2012). Multilingual competence development in the Greek educational system: FL teachers' beliefs and attitudes. International Journal of Multilingualism, 9(3), 257-271. DOI: 10.1080/14790718.2011.626857

Heugh, K. (2015). Epistemologies in multilingual education: Translanguaging and genre companions in conversation with policy and practice. Language and Education, 29(3), 280-285. DOI: 10.1080/09500782.2014.994529

Jeoffrion, C., Marcouyeux, A., Starkey-Perret, R., Narcy-Combes, M.F., \& Birkan, I. (2014). From multilingualism to plurilingualism: University students' beliefs about language learning in a monolingual context. Language, Culture and Curriculum, 27(1), 8-26.

DOI: $10.1080 / 07908318.2014 .887724$

Lewis, G., Jones, B., \& Baker, C. (2012). Translanguaging: Origins and development from school to street and beyond. Educational Research and Evaluation: An International Journal on Theory and Practice, 18(7), 641-654. DOI: 10.1080/13803611.2012.718488

Lucero, M., Valcke, M., \& Schellens, T. (2013). Teachers' beliefs and self-reported use of inquiry in science education in public primary schools. International Journal of Science Education, 35(8), 1407-1423. DOI: 10.1080/09500693.2012.704430

Luk, G.N.Y., \& Lin, A.M.Y. (2015). L1 as a pedagogical resource in building students' L2 academic literacy: Pedagogical innovation in a science classroom in a Hong Kong school. In J. Cenoz \& D. Gorter (Eds.), Multilingual education: Between language learning and translanguaging (pp. 16-34). Cambridge: Cambridge University Press.

Lyster, R., Quiroga, J., \& Ballinger, S. (2013). The effects of biliteracy instruction on morphological awareness. Journal of Immersion and Content-Based Language Education, 1(2), 169-197. DOI: 10.1075/jicb.1.2.02lys

Nishino, T. (2012). Modeling teacher beliefs and practices in context: A multimethods approach. The Modern Language Journal, 96, 380-399. DOI: 10.1111/j.1540-4781.2012.01364.x

Pajares, F. (1992). Teachers' beliefs and educational research: Cleaning up a messy construct. Review of Educational Research, 62, 307-332. DOI: 10.3102/00346543062003307

Riemersma, A., \& de Vries, S. (2011). Trilingual primary education in Fryslân. In I. Bangma, C. van der Meer, \& A. Riemersma (Eds.), Trilingual primary education in Europe (pp.4667). Leeuwarden/Ljouwert: Mercator European Research Centre on Multilingualism and Language Learning. 
Swain, M., \& Lapkin, S. (2013). A Vygotskian sociocultural perspective on immersion education: The L1/L2 debate. Journal of Immersion and Content-Based Language Education, 1(1), 101-129. DOI: 10.1075/jicb.1.1.05swa

Yang, L., \& Gao, S. (2013). Beliefs and practices of Chinese university teachers in EFL writing instruction. Language, Culture and Curriculum, 26(2), 128-145.

DOI: $10.1080 / 07908318.2013 .794817$

Young, T.J., \& Walsh, S. (2010). Which English? Whose English? An investigation of 'non-native' teachers' beliefs about target varieties. Language, Culture and Curriculum, 23(2), 123-137. DOI: $10.1080 / 07908311003797627$

\section{Laburpena}

Artikulu honetan, irakasleek hezkuntza eleaniztunaren arloan hainbat hizkuntza ikasteari buruz dituzten iritzi-usteak aztertu ditugu. Horretarako, Euskal Herriko (Espainia) eta Frisiako (Herbehereak) Lehen Hezkuntzako 51 irakasle elkarrizketatu ditugu. Bi eremuotan hiru hizkuntza irakasten dira: nagusia, gutxitua eta ingelesa. Irakasleek esandakoan oinarrituta, ikuspegi interesgarriak jaso ditugu jatorrizko hiztun idealari buruz, ikasle eleaniztunari buruz eta hizkuntza bakoitzean lortu beharko litzatekeen gaitasun mailari buruz. Irakasleek, halaber, beren ideiak azaldu dituzte hizkuntza gutxituaren eta atzerriko hizkuntzaren bitartez irakasteari buruz, eta beren iritzi-usteak adierazi dituzte irakaskuntza-jardunean hizkuntza bat baino gehiago tartekatzeaz eta horrek ikasleen errepertorio eleaniztunarekin izan dezakeen loturaz. Emaitzen arabera, badirudi gizarte-testuinguruak, eta bereziki gurasoek, hedabideek eta hizkuntzek gizartean duten estatusak, eragin handia dutela iritzi-usteen eraketan. Artikulu honen ondorio nagusi bat da iritzi-usteak oraindik hizkuntzen ikuspegi elebakarrean oinarrituta daudela, eta oso pixkanaka ari direla ikuspegi eleaniztun baterantz aldatzen.

\section{Gearfetting}

Yn dit artikel analisearje wy de mieningen fan ûnderwizers oangeande it learen fan ferskillende talen yn meartalich ûnderwiis. Yn dizze stúdzje hawwe wy fraachpetearen hâlden mei 51 basisskoalle learkrêften út Baskelân (Spanje) en Fryslân (Nederlân). Yn beide regios wurde trije talen ûnderwiisd: de mearderheidstaal, de minderheidstaal en it Ingelsk as fak en as fiertaal. Basearre op de mieningen fan de learkrêften, krije wy in nijsgjirrich ynsjoch yn it ideaal fan de 'native' sprekker, de learlingen as meartalige sprekkers, en de behearskingsnivo's foar elke taal. De learkrêften hawwe har opfettings ek jûn oer it lesjaan middels de minderheidstaal en fia it Ingelsk, likegoed as har miening oer it trochinoar hinne brûken fan talen en hoe dat yn ferbân stiet mei it meartalige repertoire. Der wurdt tocht dat de sosjale omjouwing in grutte ynfloed hat troch de âlders, de media en de status fan de talen yn de maatskippij. It artikel konkludearret dat de opfettings noch altyd foar it grutste part ientalich binne en mar bytsje by bytsje feroarje yn in mear meartalich tinken. 
Authors' addresses

Elizabet Arocena Egaña

Department of Theory and History of

Education, FICE

University of the Basque Country UPV/EHU

Tolosa Hiribidea 70

20018 Donostia-San Sebastián

Basque Country, Spain

mirenelizabet.arocena@ehu.es
Jasone Cenoz

Department of Research Methods in Education, FICE

University of the Basque Country UPV/EHU

Tolosa Hiribidea 70

20018 Donostia-San Sebastián

Basque Country, Spain

jasone.cenoz@ehu.es

Durk Gorter

Department of Theory and History of Education, FICE

University of the Basque Country UPV/EHU - IKERBASQUE

Tolosa Hiribidea 70

20018 Donostia-San Sebastián

Basque Country, Spain

d.gorter@ikerbasque.org 